\title{
Obituary: Jesus Santiago Moure
}

\author{
Danúncia Urban ${ }^{1} \&$ Gabriel A. R. Melo ${ }^{1}$
}

'Departamento de Zoologia, Universidade Federal do Paraná, Caixa Postal 19020, 81531-980 Curitiba-PR, Brasil. urban@ufpr.br; garmelo@ufpr.br

The life of Father Moure (2.11.1912 - 10.07.2010) was so intense and productive that it deserves the applause and admiration of all who knew him — colleagues and friends, students of bees, fellows from his life in the monastery and his relatives. In telling a part of his history, of his dedication to his life's work, his readiness and interest in tutoring those interested in learning about bees, we feel proud to be part of his legacy.

Jesus Santiago Moure was born 2 November 1912, in Ribeirão Preto, in the state of São Paulo. At the seminary in Rio Claro (Seminário Maior Claretiano, 1929-1932), he studied natural sciences, physics and mathematics and, of course, philosophy. He then received his degree in theology from the Seminário Maior Claretiano, in Curitiba (1933-1936). During this period his interest in insects began, as can be seen in his correspondence with the Museu Paulista (1933) and Museu Nacional, in Rio de Janeiro (1934).

In 1937, he finished his degree in theology in the city of São Paulo where he was ordained a priest on 23 May 1937. During his stay in São Paulo, he met Frederico Lane, from the Museu Paulista, by whom he was introduced to insect

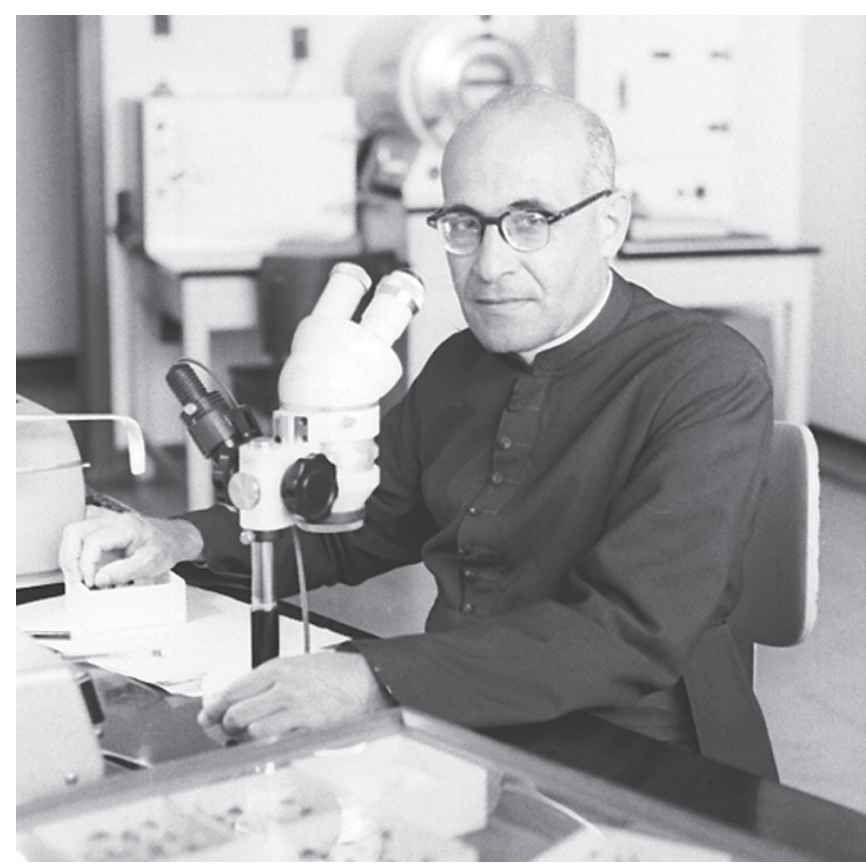

Fig. 1. Father Moure, in the 1960's, at the Universidade Federal do Paraná, in Curitiba.

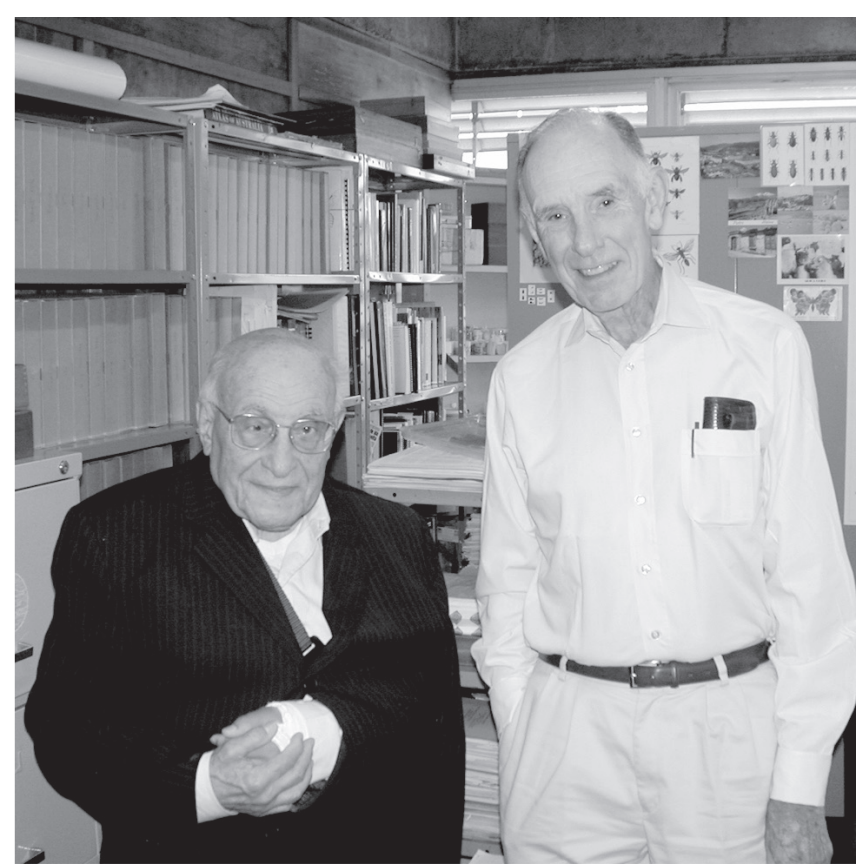

Fig. 2. Father Moure and Jerome Rozen Jr., in November 2002, at the Universidade Federal do Paraná, in Curitiba. 
taxonomy. They collaborated with three publications about curculionid beetles (Coleoptera), but then Lane suggested that Moure study bees and work with the Museu Paulista collection. This suggestion opened new horizons and sparked a very fruitful scientific career for Prof. Moure. During these early years, references and information about the Neotropical bees was hand-written or typed on small pieces of paper, thereby giving origin to his Catalogue.

Prof. Moure returned to Curitiba in 1938 as professor of Natural Sciences, Physics, Chemistry and Mathematics in the Seminário Claretiano, soon becoming involved in activities far and beyond ecclesiastical circles. As a consequence of his friendship with José Loureiro Fernandes (whom he met in the study group Círculo de Estudos Bandeirantes), he took part in founding the Faculty of Philosophy, Sciences and Letters, assuming the chair in Zoology. In 1946, this faculty was later merged with others (Medicine, Law and Engineering) to rebuild the new Universidade do Paraná.

Also invited by José Loureiro, in 1939, he became associate researcher at the Museu Paranaense, chairing the Zoology Division. One of his first acts upon assuming his chair was to burn the entire animal collection due to its precarious state of preservation and the lack of proper information about the specimens. In 1950 he took part in the restructuring of the Universidade do Paraná, which then became a federal institution, the Universidade Federal do Paraná. He subsequently became director (1952-1954) of the Museu Paranaense, during which a large collection of books and journals was purchased, thereby starting the first Zoology library of the Universidade Federal do Paraná. This library was subsequently reintegrated to the Museu Paranaense.

Except for short trips abroad, in Argentina in 1953 and Chile in 1954, Prof. Moure first traveled for an extended stay in 1956, when he went to the University of Kansas, Lawrence, in the USA. He joined Charles D. Michener and his family who were at that time returning to the USA after spending a sabbatical year in Curitiba working in collaboration with Prof. Moure. He spent six months in Lawrence, studying the bee collection, as well as attending biometry taught by Robert R. Sokal, wherein he witnessed the first steps in the development of the numerical taxonomy. In the following months, he traveled within the US to study bee collections at other universities and museums. Upon returning to Lawrence in June 1957, he received, through Michener, a grant from the US National Science Foundation to provide for a year of study in Europe, beginning in August of that year. According to his travel notes, that experience was "exceptional for his formation." While in Europe, he visited entomological collections in museums in several countries and continued his studies on bees.

Prof. Moure had to face new challenges after returning to Brazil. In his own words: "I came back with broad plans to improve our universities, and prepared a long report to Prof. Anísio Teixeira. However, my delusion was great when I saw that the Museu Paranaense [...] had not received a single penny $[\ldots]$ This museum had become a low priority institution in the state administration, and lost its affiliation with the 
Universidade do Paraná [...] I had then lost the collections and the library, my two main objectives that I had pursued during my administration. I knew of the inestimable value of both, especially in comparison with the large American and European museums." He did not give up, but rather, he wrote friends and collaborators, some foreign, and managed to get funding from the Rockefeller Foundation to rebuild the Zoology library. That library is now within, and an important part of, the Library of Biological Sciences of the Universidade Federal do Paraná (UFPR).

In subsequent travels, during the 1960's and 1970's, Prof. Moure continued his study of type material, both in Europe and in the United States. However, he had not yet had the opportunity to study the bees of the Museum für Naturkunde, in Berlin. Accompanied by Olaf H. H. Mielke, in June and August 1996, he finally realized his lifelong dream by visiting that museum. He returned to Germany the following year and again in 1999. As a result of all his travels, he compiled a total of 1,700 manuscript pages with detailed notes on the type specimens of Neotropical bees. He often carried specimens in small wood boxes to be able to compare them with the type material. His notes from these studies subsequently were very valuable for his own and his collaborators' studies.

Prof. Moure published more than 220 articles, mostly describing the bees of the Neotropical region, and often in collaboration with others. Besides Brazilian journals, he also published in scientific periodicals of the United States, Japan, Argentina and Peru. In addition to 17 family-group names, he proposed a total of 484 species-group names and 219 genusgroup names, of which around 160 of them are still valid. His main contributions to bee systematics include genus- and subgenus-level classifications for Centridini, neotropical Eucerini, Tapinotaspidini, Meliponini and Xylocopini. He also was important in establishing the basis for the classifications currently adopted in many neotropical groups, in particular the Emphorini, Nomadini (Epeolina), Diphaglossini, Paracolletini, Augochlorini, Anthidiini and Megachilini. His main incursion in the study of bees from other zoogeographic regions took place in 1961 with the publication on the Meliponini of the Old World, where he proposed new genera and identification keys to the Oriental, Australian and Ethiopian regions, after having studied type material from numerous collections.

Three books are included in Prof. Moure's publications: two were in collaboration with Paul D. Hurd Jr. and the most recent, in 2007, is the Catalogue of Bees in the Neotropical Region, organized by Profs. Moure, Urban and Melo. A total of 5,029 valid and 16 fossil bee species are catalogued. This catalogue assembles all the information gathered by Prof. Moure, beginning with his first manuscript notes and note-cards from his first visit with Michener and continuously updated throughout his productive life.

He started capturing bees for his collection on the weekends, near the seminary and in the convent gardens. Donations and acquisitions, in addition to his fulltime insect collector, Claudionor Elias, resulted in a collection that holds more than 5,000,000 pinned insects, of which around 340,000 are 
bees. Since 1982, the insect collection from the Department of Zoology of the UFPR was named Coleção de Entomologia Prof. Pe. Jesus Santiago Moure.

In the 1960's (Fig. 1), Prof. Moure was responsible for organizing the Graduate Program in Entomology of the Department of Zoology of the UFPR, with both masters and doctoral programs. He advised a total of 11 doctorates and 35 masters in the Entomology Program. From 1980 through 1996, he gave short courses in numerical taxonomy in scientific meetings, universities and research institutes in Brazil, as well as in the Universidad Nacional Autónoma de México, Universidad Nacional de la Amazonía Peruana and Pontificia Universidad Católica del Ecuador. Even after his compulsory retirement, in 1982, Prof. Moure maintained his research activities at UFPR for over 20 years (Fig. 2).

He was involved in the founding of the Conselho Nacional de Desenvolvimento Cientifico e Tecnológico-CNPq and CAPES, the two main federal funding agencies for research and science in Brazil. He also helped found the Sociedade Brasileira de Entomologia-SBE (1937), Sociedade Brasileira para o Progresso da Ciência-SBPC (1948) and the Sociedade Brasileira de Zoologia-SBZ (1978). He had a CNPq research fellowship from 1953 up to his full retirement, in 2005, when he moved to the house of the Claretian Missionaries in Batatais, São Paulo.

In 1961, he was admitted to the Brazilian Academy of Sciences, from which he received the Costa Lima Award, in 1970. Prof. Moure received many other awards and honors, including the highest honors given by the Brazilian federal government in recognition of scientific merit: Comendador da Ordem Nacional do Mérito Cientifico (1995) and GrãCruz da Ordem Nacional do Mérito Científico (1998). He was awarded an honorary doctorate from the Universidade Federal do Paraná (1982) and the title of emeritus professor (1986). In 2006, he received a diploma of emeritus researcher during the $55^{\text {th }}$ anniversary of CNPq.

Prof. Moure dedicated himself to both science and ecclesiastical duties. He often said "God made the world through evolution and we attempt, the best we can, to rewrite the history of this world." When celebrating the religious marriage of a colleague or collaborator, in his sermon he would make frequent and relevant reference to his many scientific travels.

Father Jesus Santiago Moure, an icon of Brazilian science, passed peacefully away on the $10^{\text {th }}$ of July 2010 , at 97 years of age, in the house of the Claretian Missionaries in Batatais, São Paulo.

Acknowledgements. We would like to thank Prof. Albino Sakakibara for providing the photography used as Fig. 1, and Dr. James Roper for reviewing the grammar and style of the English version.

Received 18/08/2010; accepted 26/08/2010

Editor: Claudio José Barros de Carvalho 